\title{
Diarrhoeal Diseases in Developing Countries: A Situational Analysis
}

Kumar SG, Subita L

Preventive and Social Medicine

Jawaharlal Institute of Postgraduate Medical Education and Research (JIPMER),

Puducherry, India

\section{Corresponding Author}

Ganesh Kumar S

Preventive and Social Medicine

Jawaharlal Institute of Postgraduate Medical Education and Research (JIPMER), Puducherry, India

Email: sssgan@yahoo.com

Citation

Kumar S G, Subita L.Diarrhoeal Diseases in Developing Countries: A Situational Analysis. Kathmandu Univ Med J 2012;38(2):83-88.

\begin{abstract}
Recent data showed that there is no much reduction in diarrhoea related morbidity in developing countries. This is important in view of the Millennium Developmental Goal (MDG) to be achieved by 2015 . This study reviewed and analyzed after gathering the recent literature information from Pubmed, internet and other sources. The authors discussed public health issues related to diarrhoeal diseases that include problem burden, determinants, intervention strategies, management, prevention and recent developments for control of diarrhoea among under-five children in developing countries. The study emphasizes the need for strengthening of comprehensive diarrhoeal disease prevention strategy at primary level including improvement of water quality, hygiene and sanitation, along with provision of oral rehydration solution and zinc supplements, and research in the field of vaccine and cost effective interventions.
\end{abstract}

\section{KEY WORDS}

Diarrhoea, Developing countries, Situational analysis

\section{INTRODUCTION}

Diarrhoeal disease is an important public health problem among under- five children in developing countries. Global estimates of the mortality due to diarrhoea have shown a steady decline sine 1980s. However, diarrhoeal diseases still continue to be an important cause of morbidity and mortality worldwide in spite of all advances in health technology, improved management, and increased use of oral rehydration therapy in the past decades. Morbidity due to diarrhoea has not shown a parallel decline in comparison to mortality trends, and global estimates remain between two and three episodes of diarrhoea per under five year child per year. ${ }^{1}$ Millenium Development Goal - 4 aims to reduce childhood mortality by $2 / 3$ by the year 2015 and previous studies, however, show minimal progress in this regard. So efforts must be made to review existing strategies and formulate newer ones. ${ }^{2}$
There are multiple reasons for poor declining trend of diarrhoeal diseases especially in developing countries with the environmental sanitation issues contributing a major part of it. A recent review highlighted the fact that there is a need for prioritisation of certain interventional strategies with respect to environmental sanitation in India. ${ }^{3}$ This is in view of changing pattern of exposure to risk factors at various levels for water borne diseases including urbanisation and industrialisation. Because of the above findings, it is important to analyse the diarrhoeal disease morbidity pattern and factors associated with it, preventive and control strategies with recent developments, so that appropriate control measures can be adopted at various levels in the community. 


\section{METHODS}

Recent data was collected from Google search engine, Pubmed and others. Key words used were diarrhoeal diseases, developing countries, problem burden, risk factors, aetiology, interventional strategies, and vaccines. Data pertaining to developing countries after the year 2000 was collected, summarised and analysed for discrepancies. Information was described in terms of problem burden, determinants, intervention strategies, management, prevention and recent developments for control of diarroea among under-five children.

\section{Problem Burden and determinants}

Diarrhoeal disease was the second leading cause of death among under-five children in low-income countries in 2004 after pneumonia and it kills 1.5 million children every year. In developing countries, children under three years old experience on average three episodes of diarrhoea every year. ${ }^{4} \mathrm{~A}$ review of the incidence and prevalence of acute gastrointestinal illness from 33 studies in developed countries reported it to be ranging from 0.1 to 3.5 episodes per person-year. ${ }^{5}$ In India, the proportionate mortality due to diarrhoea was $9.1 \%$ and the estimated projection of Years of Life Lost (YLL) will increase from 1,68,896 in 2006 to $1,95,046$ in 2016 among 0 to 6 years age group. ${ }^{6}$

Table 1. Problem burden of diarrhoeal diseases.

\begin{tabular}{|c|c|c|c|c|}
\hline Country ${ }^{\text {Ref }}$ & Year & $\begin{array}{l}\text { Type of } \\
\text { study }\end{array}$ & Age group & Findings \\
\hline India $^{7}$ & 2003 & $\begin{array}{l}\text { Community } \\
\text { based }\end{array}$ & $\begin{array}{l}\text { All age } \\
\text { groups }\end{array}$ & $\begin{array}{l}5.27 \% .15 \% \\
\text { were less } \\
\text { than } 2 \text { years } \\
\text { age }\end{array}$ \\
\hline India ${ }^{8}$ & 2010 & $\begin{array}{l}\text { Community } \\
\text { based }\end{array}$ & $\begin{array}{l}\text { All age } \\
\text { groups }\end{array}$ & $3.58 \%$ \\
\hline Egypt ${ }^{9}$ & 2000 & Sentinel sites & Under five & $\begin{array}{l}19.5 \%, 3.6 \\
\text { episodes per } \\
\text { child semian- } \\
\text { nually }\end{array}$ \\
\hline Ethiopia ${ }^{10}$ & 2000 & $\begin{array}{l}\text { Community } \\
\text { based }\end{array}$ & Under five & $15 \%$ \\
\hline Ethiopia ${ }^{11}$ & 2003 & $\begin{array}{l}\text { Community } \\
\text { based }\end{array}$ & Under five & $\begin{array}{l}42.6 \% .5 .48 \\
\text { episodes per } \\
\text { child per year }\end{array}$ \\
\hline Ethiopia ${ }^{12}$ & 2008 & $\begin{array}{l}\text { Community } \\
\text { based }\end{array}$ & Under five & $28.9 \%$ \\
\hline Iraq $^{13}$ & 2000 & $\begin{array}{l}\text { Community } \\
\text { based }\end{array}$ & Under five & $21.3 \%$ \\
\hline Israel ${ }^{14}$ & 2011 & $\begin{array}{l}\text { Population } \\
\text { based }\end{array}$ & $\begin{array}{l}\text { Less than } 17 \\
\text { years }\end{array}$ & $5.7 \%$ \\
\hline Malaysia ${ }^{15}$ & 2011 & $\begin{array}{l}\text { Population } \\
\text { based }\end{array}$ & $\begin{array}{l}\text { All age } \\
\text { groups }\end{array}$ & $\begin{array}{l}5 \% \text { in past } 4 \\
\text { weeks }\end{array}$ \\
\hline $\begin{array}{l}\text { United } \\
\text { States }{ }^{16}\end{array}$ & 2002 & $\begin{array}{l}\text { Population } \\
\text { survey }\end{array}$ & $\begin{array}{l}\text { All age } \\
\text { groups }\end{array}$ & $\begin{array}{l}11 \% \text { in the } \\
\text { past } 4 \text { weeks }\end{array}$ \\
\hline $\begin{array}{l}\text { United } \\
\text { States }^{17}\end{array}$ & 2007 & $\begin{array}{l}\text { Population } \\
\text { survey }\end{array}$ & $\begin{array}{l}\text { All age } \\
\text { groups }\end{array}$ & $\begin{array}{l}5.1 \% \text { in the } \\
\text { past } 4 \text { weeks }\end{array}$ \\
\hline
\end{tabular}

The Egypt and Ethiopia studies showed that 33.6\%, 24.5\% and $14 \%$ of the acute diarrhoeal diseases had persistent diarrhoea. ${ }^{9-11}$ The risk factor analysis were varied in different studies. A hospital based data from Bangladesh reported that more diarrheal patients admitted were above five years of age (64\%) than those below five years of age (36\%). About $60 \%$ of the patients above five years of age had severe dehydration compared with only $9 \%$ of patients under five years of age. ${ }^{18}$

Egypt study reported that in order of contribution to risk prediction, household meat consumption, mother's age at the time of birth of the child, child's age, and father's illiteracy were significant factors, while Ethiopia study found that well source of water and acute respiratory infections (ARI) in the previous two weeks were found to be significantly associated with occurrence of diarrhoeal disease in the logistic regression analysis. ${ }^{9,11}$ Another study found that use of cover material during drinking water transportation, faeces seen around the pit-hole and bottle feeding were the only significant variables on multivariate analysis. ${ }^{12}$ In contrast to this another study in Ethiopia found that young age, male gender, living in a house with fewer number of rooms, and obtaining water from storage containers by dipping showed statistically significant association with diarrheal morbidity while type of water source, amount of water consumed, and latrine availability were not found to be significant risk factors. ${ }^{10}$ Iraq study showed that $6.9 \%$ of under-five children also had acute respiratory infection (ARI) in the last two weeks and diarrhoea was associated with age of child, area of residence, maternal education, source of water, toilet facility, disposal of children' stool and disposal of dirty water. ${ }^{13}$ Indian studies found that household member with cholera during the period of surveillance, young age, lower educational level and non-potable water at storage points was associated with water borne diseases. ${ }^{7,8}$

At the same time it is important to look for the quality of water distribution system from the source. As found out in Borakhpur, India, bacteriological pollution of drinking water supplies due to the infiltration of contaminated water through cross connection, leakage points, and back siphoning caused diarrheal illness. ${ }^{19}$ The significant water risk factors as identified were the mode of water transportation, and the poor handling of water at the household level, including lack of or inappropriate water treatment methods. These, combined with the low education level further pre dispose the under five children to diarrhoea. ${ }^{20}$ Also, washing and purifying fruit and vegetables; presence of wastewater in the street; refuse storage, collection and disposal; domestic water reservoir conditions; faeces disposal from swaddles; presence of vectors in the house and flooding in the lot were found to be associated with diarrhoea. ${ }^{21}$ Amongst households storing municipal water proven to be safe at source, adhering to the best storage practices did not translate into lower incidence rates as compared to those with relatively unsafe practices. The explanation lay in factors which were external to the home and beyond the control of the affected household. Thus, household level behavioural factors such as storage practises should not be analysed in isolation as determinants of diarrhoeal illness particularly 
when pitted against stronger neighbourhood and external determinants. $^{22}$

\section{Aetiology}

A study in Bangladesh found that the most prevalent pathogen isolated was Vibrio cholerae 01 (23\%) followed by ETEC (11\%). About $8 \%$ of cholera infection was seen in infants with the youngest children being one month of age while in the case of ETEC the rate was $11 \%$. Of the isolated ETEC strains, the enterotoxin type were almost equally distributed; ST accounted for $31 \%$ of strains; LT/ST for $38 \%$ and LT for $31 \% .{ }^{18}$ During the dry season, acute watery diarrhoea is the most common type of diarrhoea in children under five years in a study in Tanzania and overall, bacteria and viruses contributed equally accounting for $33.2 \%$ and $32.2 \%$ of all the cases, respectively. ${ }^{23}$ Of the estimated 165 million cases of Shigella diarrhoea that occur annually, $99 \%$ occur in developing countries out of which $69 \%$ of episodes occur in children under five years of age. Moreover, of the ca.1.1 million deaths attributed to Shigella infections in developing countries, $60 \%$ of deaths occur in the underfive age group. ${ }^{24}$

A recent study from China showed that $46.48 \%$ of diarrhoea among young children are due to viral aetiology with rotavirus infections were the most common, followed by adenovirus infections, norovirus infections and astrovirus infections. Children younger than one year old were the most susceptible population to viral infections (87.9\%). ${ }^{25}$ Uganda and Turkey studies showed that prevalence of rotavirus infection was $45.4 \%$ and $44.4 \%$. ${ }^{26,27}$

Another hospital based study from India found that about $3.6 \%$ of the cases were positive for E. histolytica. No seasonality was observed although in the neighboring tropical country Bangladesh, a typical seasonality of E. histolytica infection was noticed. ${ }^{28}$ A Nigerian study showed that out of 300 under-five children with diarrhea, $70(23.3 \%)$ had parasites. There were $18(6 \%)$ helminthes and $52(17.3 \%)$ protozoas. Malnutrition and low socioeconomic status are risk factors. ${ }^{29}$ A recent study in South Asia, South East Asia and Far East found that prevalence of $\mathrm{G}$. lamblia varied markedly between studies illustrating higher levels in the urban than in the rural areas, more among poor communities, slightly higher in males than in females with age range of 2-5-year-old children, and among university students, old-aged people, HIV-positive patients, and gastric carcinoma patients. ${ }^{30}$ Prevalence rates of Giardia infection in patients with diarrhoea range from $0.4 \%$ to $70 \%$, and asymptomatic cyst passage has been found to be as high as $50 \%$ in rural southern India. ${ }^{31}$

\section{Intervention strategies}

A systematic review showed that based on current evidence, washing hands with soap can reduce the risk of diarrhoeal diseases by $42-47 \% .{ }^{32-33}$ Compared with children living in households where persons prepared food without washing their hands, children living in households where the food preparer washed at least one hand with water only (odds ratio $=0.78)$, washed both hands with water only $(O R=0.67)$, or washed at least one hand with soap $(O R=0.30)$ had less diarrhoea. In households where residents washed at least one hand with soap after defecation, children had less diarrhoea $(O R=0.45)$. There was no significant association between hands washing with or without soap before feeding a child, before eating, or after cleaning a child's anus who defecated and subsequent child diarrhoea and hand washing with water alone can significantly reduce childhood diarrhoea. ${ }^{34}$ Having water available at the place to wash hands after toileting (odds ratio $=2.2$ ) and having soap available at the place to wash hands after toileting (odds ratio $=2.1$ ) were associated with washing both hands with soap after fecal contact. ${ }^{35}$ These observations suggest that hand washing before preparing food is a particularly important opportunity to prevent childhood diarrhoea. With an intense community-based intervention and supplies provided free of cost, each of the home-based interventions significantly reduced diarrhoea. There was no benefit by combining hand washing promotion with water treatment. ${ }^{36}$

Access to improved sanitation was associated with lower mortality $(O R=0.77)$, a lower risk of child diarrhoea $(O R=0.87)$ and a lower risk of mild or severe stunting $(O R=0.73)$. Access to improved water was associated with a lower risk of diarrhoea $(O R=0.91)$ and a lower risk of mild or severe stunting (OR $=0.92)$, but did not show any association with non-infant child mortality $(O R=0.97) .{ }^{37}$ The long-term impact of the floods was not clearly marked in the overall prevalence of diarrhoea with the exposed group having prevalence of $55.1 \%$ as against $56.2 \%$ in the unexposed group of children under five. ${ }^{38}$ Diarrhoea is positively correlated with earth eating $(r=0.306)$, presence of human faeces in the yard $(r=0.587)$, presence of animal faeces in the yard $(r=0.225)$ and the index child not wearing loincloth $(r=0.471){ }^{39}$

The effect of increasing maternal education appears to be more protective for children in wealthy families than for children in poor families. Conversely, improvements in economic status reduce health risks more for children whose mothers are better educated. Father's education is protective and operates independently of economic status. Our findings imply that poverty alleviation efforts occurring in concert with programs to educate women and girls will be more effective for improving children's health than either approach alone. ${ }^{40}$

Newly available data set District Level Household Survey 3 to quantify the impact of access to improved sanitation on diarrheal morbidity for children less than 5 years of age in India found that access to improved sanitation reduces the risk of contracting diarrhoea by 2.2 percentage points. There is considerable heterogeneity in the impacts of improved sanitation and the magnitude of the treatment effect differs largely by hygiene behaviour. ${ }^{41}$ 
In case of persistent diarrhoea, micronutrient supplementation, algorithm based diet regimens, and good supportive care are sufficient in most children with above six months of age. ${ }^{42}$ More data are needed to optimize the management of diarrhoea and highlight the research priorities at a global level; such priorities include improved recommendations on oral rehydration solution composition, and the re-evaluation of therapeutic options in the light of new trials. Therapeutic strategies need to be assessed in different settings, and pharmaco-economic analyses based on country-specific data are needed. ${ }^{43}$

\section{CONSEQUENCES}

Diarrhoea is a contributing factor of anaemia and malnutrition among young children. ${ }^{44}$ Diarrhoea may contribute substantially the burden of Acute Lower Respiratory tract Infection in malnourished populations. ${ }^{45}$ The absence of peripheral pulses even after full rehydration, severe malnutrition, hypoxaemia, lobar pneumonia and hypernatraemia are independent predictors of death among the under-five children with diarrhoea admitted to critical care ward of a resource-limited setting in Bangladesh. ${ }^{46}$ Pneumonia was the most common immediate cause of death [29.7\%] followed by acute diarrhea and malaria each contributing for $23 \%$ of deaths. ${ }^{47}$

\section{Recent developments}

The vaccine for rota virus has been launched in 62 countries and has been included the national immunization schedule in 11 countries. The Strategic Advisory Group of Experts (SAGE) recommends the inclusion of rotavirus vaccination of infants into all national immunization programs. The vaccine should be administered promptly after reconstitution as a $1 \mathrm{ml}$ oral dose. The vaccine should be given in two doses. The first dose should be administered at the age of 6 weeks and no later than at the age of 12 weeks. The interval between the 2 doses should be at least four weeks. ${ }^{48}$ All the studies concluded that rotavirus immunization is cost effective but may not be affordable for the developing world at present. Developing countries will definitely rely on financial support from international organizations to introduce rotavirus vaccination. ${ }^{49}$

Constant antibiotic surveillance is warranted as bacteria were highly resistant to various antimicrobial agents including co-trimoxazole and erythromycin which are currently recommended for empiric treatment of diarrhoea. ${ }^{23}$ New methods for prevention, management, and treatment of diarrhoea-including an improved oral rehydration formulation, zinc supplementation, and rotavirus vaccines-make now the time to revitalise efforts to reduce diarrhoea mortality worldwide. ${ }^{50}$ The addition of zinc and prebiotics to ORS limits diarrhoea duration in children. ${ }^{51}$ The incidence of diarrhoea showed a $13 \%$ reduction with preventive zinc supplementation. ${ }^{52}$ Preventive vitamin A supplementation reduces all-cause and diarrhea specific mortality in children 6-59 months of age in community settings in developing countries. ${ }^{53}$

The oral killed WC/rBS cholera vaccine (DukoralTM) was found to prevent $23 \%$ of all diarrhoea episodes and $52 \%$ of episodes due to ETEC in Finnish tourists visiting Morocco. This protection was reported, however, not to last more than a few months. The protective efficacy of the rCTB-CF ETEC vaccine was assessed in two larger placebo-controlled Phase III trials in American travellers going to Mexico and Guatemala. The only paediatric study to assess efficacy of the $\mathrm{rCTB}-\mathrm{CF}$ ETEC vaccine was undertaken in rural Egypt with 350 children of 6-18 months old. Several other approaches are being pursued to develop specific ETEC vaccines using a new delivery technology, the transcutaneous immunization patch. ${ }^{54-55}$ The introduction of TF vaccines in routine vaccination programs in Asia would be highly beneficial in view of the burden of disease and cost of illness to governments and individuals. However, most developing countries are uncertain of their true TF disease burden, due to lack of rapid diagnostic tools, infrequency of laboratory testing and poor reporting system. So far, only two countries, China and Vietnam, have incorporated typhoid vaccination into their routine immunization programs, and only in a limited fashion. Two new vaccines are currently licensed and widely used worldwide, a subunit (Vi PS) vaccine administered by the intramuscular route and a live attenuated S. typhi strain (Ty21a) for oral immunization. ${ }^{54}$ As the majority of childhood diarrhoeas are caused by V. cholerae, Shigellae dysenteriae type 1, rotavirus and enterotoxigenic Escherichia coli (E. coli) which have a high morbidity and mortality, vaccines against these organisms are essential for the control of epidemics. A strong political will with appropriate budgetary allocation is essential for the control of childhood diarrhoeal diseases in India, a formidable task in a country with a population of over one billion. ${ }^{56}$

\section{CONCLUSION}

With high morbidity and mortality prevailing among children in developing countries due to diarrheal diseases, achieving Millennium Development Goal 4 (MDG 4), which aims to reduce the global under-five mortality rate by two thirds between 1990 and 2015, will require additional efforts. The governments should focus on comprehensive diarrhoeal disease control strategy, including improvement of water quality, hygiene, and sanitation; provision of oral rehydration solution and zinc supplements; overall improved case management and research in the field of cost effective interventions. Existing public health programs should develop effective approaches to promote hand washing that cost less and can be used to reach millions of at risk households. A strong political will with appropriate budgetary allocation along with monitoring and follow up evaluation are essential for the control of childhood diarrhoeal diseases in developing countries. 


\section{REFERENCES}

1. World Health Organization. Diarrhoeal Diseases. [Last accessed on 16th April 2012]. Available from http://www.who.int/mediacentre/ factsheets/fs330/en/index.html.

2. Alkizim F, Matheka D, Murithi A. Childhood diarrhoea: failing conventional measures, what next? Pan Afr Med Journal. 2011; 8:47.

3. Ganesh Kumar S, kar SS. Health and Environmental sanitation in India: Issues for prioritising control strategies. Indian J occup Environ Med. 2011; 15:93-6.

4. The world Bank. Diarrhoeal diseases. [Last accessed on 12th April 2012] Available from http://www.ncbi.nlm.nih.gov/books/NBK2302/.

5. Roy SL, Scallen E, Beach MJ. The rate of acute gastrointestinal illness in developed countries. J Water Health. 2006; 4 Suppl 2:31-69.

6. World Health organisation. Estimation of the burden of diarrhoeal diseases in India. [Last accessed on 10th April 2012]. Available from http://ww.whoindia.org/Commission_On_macroeconomic_and-

7. Sur D, Deen JL, Manna B, Niyogi SK, Deb AK, Kanungo $S$ et al. The burden of cholera in the slums of Kolkata, India: data from a prospective, community based study. Arch Dis Child. 2005;90:117581.

8. Jadhav J. Bacteriological quality of water and water borne diseases in Bangalore: a longitudinal study. East Afr J Public Health. 2011;8:42-4.

9. Yassin K. Morbidity and risk factors of diarrheal diseases among under-five children in rural Upper Egypt. J Trop Pediatr. 2000t;46:2827.

10. Teklemariam S, Getaneh T, Bekele F. Environmental determinants of diarrheal morbidity in under-five children, Keffa-Sheka zone, south west Ethiopia. Ethiop med Journal 2000;38:27-34.

11. Mekasha A, Tesfahun A. Determinants of diarrhoeal diseases: a community based study in urban south western Ethiopia. East Afr Med J. $2003 ; 80: 77-82$

12. Eshete WB. A stepwise regression analysis on under-five diarrhoael morbidity prevalence in Nekemte town, western Ethiopia: maternal care giving and hygiene behavioral determinants. East Afr J Public Health. 2008;5:193-8.

13. Siziya $S$, Muula AS, Rudatsikira E. Diarrhoea and acute respiratory infections prevalence and risk factors among under-five childrenin Iraq in 2000. Ital J Pediatr. 2009;35:8.

14. Ziv T, Heymann AD, Azuri J, Leshno M, Cohen D. Assessment of the underestimation of childhood diarrhoeal disease burden in Israel. Epidemiol Infect 2011; 139: 1379-87.

15. Gurpreet K, Tee GH, Amal NH, Paramesarvathy R, Karuthan C. Incidence and determinants of acute diarrhoea in Malaysia: a population-based study. Journal of Health Popul Nutr. 2011; 29: 10312.

16. Herikstad H, Yang S, Van Gilder TJ, Vugia D, Hadler J,Blake P et al. A population-based estimate of the burden of diarrhoeal illness in the United States: FoodNet, 1996-7. Epidemiol Infect. 2002; 129: 9-17.

17. Jones TF, McMillan MB, Scallen E, Frenzen PD, Cronquist AB, Thomas $S$ et al. A population-based estimate of the substantial burden of diarrhoeal disease in the United States; FoodNet, 1996-2003. Epidemiol Infect. 2007; 135:293-301.

18. Chowdhury F, Rahman MA, Begum YA, Khan Al, Faruque AS, Saha NC et al. Impact of rapid urbanization on the rates of infection by Vibrio cholerae 01 and enterotoxigenic Escherichia coli in Dhaka, Bangladesh. PLoS Negl Trop Dis. 2011;5:e999.

19. Abdul RM, Mutnuri L, Dattatreya PJ, Mohan DA. Assessment of drinking water quality using ICP-MS and microbiological methods in the Bholakpur area, Hyderabad, India. Environ monit assess. 2011; 184:1581-92
20. Simiyu S. Water risk factors pre-disposing the under five children to diarrhoeal morbidity in Mandera district, Kenya. East Afr J Public Health. $2010 ; 7: 353-60$.

21. Heller L, Colosimo EA, Antunes CM. Environmental sanitation conditions and health impact: a case-control study. Rev Soc Bras Med Trop. 2003;36:41-50.

22. Rajib Dasgupta. Exploring intrahousehold factors for diarrhoeal diseases: A study in slums of Delhi, India. Journal of Water and Health. 2008; 6:289-99.

23. Moyo SJ, Gro N, Matee MI, Kitundu J, Myrmel H, Mylvaganam H et al. Age specific aetiological agents of diarrhoea in hospitalized children aged less than five years in Dar es Salaam, Tanzania. BMC Pediatr. 2011;11:19.

24. Niyogi SK. Shigellosis. J Microbiol. 2005;43:133-43.

25. Ouyang $\mathrm{Y}, \mathrm{Ma} \mathrm{H}$, Jin $\mathrm{M}$, Wang $\mathrm{X}$, Wang $J$, $\mathrm{Xu} L$ et al. Etiology and epidemiology of viral diarrhea in children under the age of five hospitalized in Tianjin, China. Arch Virol 2012 Feb 9.

26. Nakawesi JS, Wobudeya E, Ndeezi G, Mworozi EA, Tumwine JK. Prevalence and factors associated with rotavirus infection among children admitted with acutediarrhea in Uganda. BMC Pedatr. 2010;10:69.

27. Ozdemir S, Delialioğlu N, Emekdaş G. Investigation of rotavirus, adenovirus and astrovirus frequencies in children with acute gastroenteritis and evaluation of epidemiological features. Mikrobiyol Bul. 2010 ;44:571-8.

28. Mukherjee AK, Das K, Bhattacharya MK, Nozaki T, Ganguly S. Trend of Entamoeba histolytica infestation in Kolkata. Gut pathog. 2010 ;2:12.

29. Tinuade O, John O, Saheed O, Oyeku O, Fidelis N, Olabisi D. Parasitic etiology of childhood diarrhea. Ind J Pediatrics. 2006;73:1081-4.

30. Dib HH, Lu SQ, Wen SF. Prevalence of Giardia lamblia with or without diarrhea in South East, South East Asia and the Far East. Parasitol Res 2008 ; 103:239-51.

31. Laishram S, Kang G, Ajjampur SS. Giardiasis: a review on assemblage distribution and epidemiology in India. Indian J Gastroenterol. 2012 ;31:3-12.

32. Luby SP, Agboatwalla M, Feikin DR, Painter J, Billhimer W, Altaf A et al. Effect of handwashing on child health: a randomised controlled trial. Lancet. 2005;366(9481):225-33.

33. Val Curtis, Sandy Cairncross. Effect of washing hands with soap on diarrhoea risk in the community: a systematic review. The Lancet Infectious Diseases. 2003; 3: 275 - 81 .

34. Luby SP, Halder AK, Huda T, Unicomb L, Johnston RB. The effect of handwashing at recommended times with water alone and with soap on childdiarrhea in rural Bangladesh: an observational study. PLOS Med. $2011 ; 8(6)$ :e1001052.

35. Luby SP, Halder AK, Tronchet C, Akhter S, Bhuiya A, Johnston RB Household characteristics associated with handwashing with soap in rural Bangladesh. Am J Trop Med Hyg. 2009 ;81:882-7.

36. Luby SP, Agboatwalla M, Painter J, Altaf A, Billhimer W, Keswick B et al. Combining drinking water treatment and hand washing for diarrhoea prevention, a cluster randomised controlled trial. Trop Med Int Health 2006;11:479-89.

37. Fink G, Günther I, Hill K. The effect of water and sanitation on child health: evidence from the demographic and health surveys 19862007. Int J Epidemiol. $2011 ; 40: 1196-204$.

38. Joshi PC, Kaushal S, Aribam BS, Khattri P, D'Aoust O, Singh MM et al. Recurrent floods and prevalence of diarrhea among under five children: observations from Bahraich district, Uttar Pradesh, India. Global Health Action 2011;4.

39. Shivoga WA, Moturi WN. Geophagia as a risk factor for diarrhoea. J infect Dev Ctries. 2009;3:94-8. 
40. Hatt LE, Waters HR. Determinants of child morbidity in Latin America: a pooled analysis of interactions between parental education and economic status. Soc Sci Med. 2006;62:375-86.

41. Kumar S, Vollmer $S$. Does access to improved sanitation reduce childhood diarrhea in rural India. Health Econ 2012.

42. Mathai J, Raju B, Bavdekar A. Chronic and persistent diarrhea in infants and young children: status statement. Indian Pediatr. 2011;48:37-42.

43. Guarino A, Dupont C, Gorelov AV, Gottrand F, Lee JK, Lin Z et al. The management of acute diarrhea in children in developed and developing areas: from evidence base to clinical practice. Expert Opin Pharmacother. 2012 ;13:17-26.

44. Howard CT, de Pee S, Sari M, Bloem MW, Semba RD. Association of diarrhea with anemia among children under age five living in rural areas of Indonesia. J Trop Pediatr. 2007;53:238-44.

45. Schmidt WP, Cairncross S, Barreto ML, Clasen T, Genser B. Recent diarrhoeal illness and risk of lower respiratory infections in children under the age of 5 years. International J of Epidemiology. 2009;38: 766-72.

46. Chisti MJ, Pietroni MA, Smith JH, Bardhan PK, Salam MA. Predictors of death in under-five children with diarrhoea admitted to a critical care ward in an urban hospital in Bangladesh. Acta Pediatrics 2011;100:275-9.

47. Girma B, Berhane Y. Children who were vaccinated, breast fed and from low parity mothers live longer: a community based case-control study in Jimma, Ethiopia. BMC Public Health. 2011;11:197.

48. Verma R, Khanna $P$, Chawla $S$. Rotavirus vaccine can save millions of children's lives in developing countries. Hum vaccin Immunother. 2012;8(2).
49. Tu HA, Woerdenbag HJ, Kane S, Rozenbaum MH, Li SC, Postma MJ. Economic evaluations of rotavirus immunization for developing countries: a review of the literature. Expert Rev Vaccines. 2011 ;10:1037-51.

50. Santosham M, Chandran A, Fitzwater S, Fischer-Walker C, Baqui AH, Black R. Progress and barriers for the control of diarrhoeal disease. Lancet. 2010 3;376(9734):63-7.

51. Passariello A, Terrin G, De Marco G, Cecere G, Ruotolo S, Marino A et al. Efficacy of a new hypotonic oral rehydration solution containing zinc and prebiotics in the treatment of childhood acute diarrhea: a randomized controlled trial. J Pediatr. 2011;158(2):288-92.

52. Yakoob MY, Theodoratou E, Jabeen A, Imdad A, Eisele TP, Ferguson $J$ et al. Preventive zinc supplementation in developing countries: impact on mortality and morbidity due to diarrhea, pneumonia and malaria. BMC Public health. 2011;11 Suppl 3:S23.

53. Imdad A, Yakoob MY, Sudfeld C, Haider BA, Black RE, Bhutta ZA. Impact of vitamin A supplementation on infant and childhood mortality. BMC Public Health. 2011;11 Suppl 3:S20.

54. WHO Diarrheal diseases: Initiatives or Vaccine Research. [last accessed on 2012 April 20]. Accessed from http://www.who.int/ vaccine_research/diseases/diarrhoeal/en/index5.html.

55. Svennerholm A. From cholera to enterotoxigenic Escherichia coli (ETEC) vaccine development. Indian J Med Res. 2011; 133: 188-194.

56. Bhattacharya SK. Progress in the prevention and control of diarrhoeal diseases since Independence. Natl Med J India. 2003;16 Suppl 2:15-9. 